\title{
The importance of product positioning and global branding for sustaining competitive advantage within the companies' global marketing strategy
}

\author{
Aslı Küçükaslan Ekmekçi \\ (Department of Business Administration, Faculty of Economics and Administrative Sciences, \\ Marmara University, Istanbul 34722, Turkey)
}

\begin{abstract}
In today's globally competitive world, because of the globalization, new business patterns and the changing nature of consumers, the companies feel the necessity to act strategic in the market and to reach up the target markets and sustain maximum customer satisfaction in order to compete and survive. In this context, within the study it is tried to define product positioning in international markets and global branding strategies conceptually and to focus on their contributions to the overall competitive advantage of the company. Initially, the study tries to present the association between product positioning and global branding approaches of the companies and sustaining competitive advantage. Justifications for the examination of the importance of companies' international product positioning and global branding orientations as a basis of creating competitive advantage were derived from the literature. It is suggested that the companies' product positioning and global branding orientations and sustaining competitive advantage are the important aspects in multinational management and international business areas. Therefore, the purpose of this study is to evaluate the impact of product positioning and global branding strategies of the companies with special references to various industries and global brands.
\end{abstract}

Key words: globalization; global branding; product positioning; competitive advantage; international business

\section{Introduction}

Globalization has been seen particularly at the beginning of 1980s, and there have occurred many changes in marketing and other functions of the companies. With those changes, all of the companies have existed face to face in a common market. In this new global market, the core of success has become to be products and globally known brands. Moreover, customer demands have become homogeneous and product-service quality has reached up high levels in global markets. All those factors and the growing competition have been the major factors that that the companies concern about.

In order to compete in the market, the companies' managers should evaluate the major characteristics of the market and their products. The markets bring the companies both essential opportunities and difficulties. In other words, the companies have to develop effective competitive strategies in order to survive in the market.

A large number of companies compete against each other in the market and each company tries to gain competitive advantage in the market by delivering more product "value" as compared to its competitors. Several

Aslı Küçükaslan Ekmekçi, associate professor, Department of Business Administration, Faculty of Economics and Administrative Sciences, Marmara University; research fields: business management, product positioning, global branding, mergers and acquisitions. 
factors and issues go into the creation of a sustained competitive advantage for a company. It is stated that an organization's competitive advantage involves gaining an advantage over other competing companies with regard to the design and delivery of the product or service. Gaining competitive advantage requires a set of specialized skills, assets, and capabilities for the organization. It is also added that the competitive advantage is the measure of a company's competencies and performance against the factors prevailing in the company's external environment (http://jobfunctions.bnet.com). Therefore, competitive strategy is all about identifying and exploiting opportunities to gain competitive advantage.

In this context, it is mentioned that (Rodríguez-Pinto, Rodríguez-Escudero \& Gutiérrez-Cillán, 2008, p.154) the companies operate in increasingly dynamic and turbulent environments characterized by intense competition, uncertain market conditions, faster technological changes and shorter product life cycles. At this point, the effective positioning of the products in the market can be considered as a critical factor for the achievement of the competitive advantage of the companies.

\section{Literature review}

\subsection{Competitive advantage and competitive strategies}

The term competitiveness stems from the analysis of companies and is usually thought to be defined at the company level. However, recently the notion competitiveness has become a prominent concept in the assessment of countries, regions and locations. As it is stated, the issues of competitive advantage of nations and the competitiveness of locations became important topics in economics and business fields (Aiginger, 2006, p.63). However, the interest in this field has been stimulated and increased by the work of Michael Porter.

Porter (1990) proposed his conceptual framework for competitiveness firstly in his study called "the competitive advantage of nations". Porter defined "the competitiveness of a location as the productivity that companies located there could achieve, and he used this definition of competitiveness to understand the drivers of sustainable economic prosperity at a given location (Ketels, 2006, p.116)".

When the concept of competitive advantage is examined, it is seen that competitive advantage is the basis for superior performance and understanding the anatomy of competitive advantage has crucial importance for general managers who bear the ultimate responsibility for a company's long term survival and success (Ma, 1999, p.709). It is suggested that a company needs a rationale to justify its existence, and that rationale is mentioned as to create value better than rivals can; to contribute to the society in ways that are unique and indispensable. These are all important questions concerning the multiple facets of the anatomy of competitive advantage (Ma, 1999, p.709).

As competitive advantage entails various shapes and sizes, to understand the features of competitive advantage would help the managers to improve their companies' chance of gaining and sustaining competitive advantage and their chance of creating value. Strategy involves choice of a company's scope of product market activities (Porter, 1980) and "the company should decide what kind of value it wants to deliver to whom" (Porter, 1999, p.14). On the other hand, strategy involves the combination of its resources and capabilities (Barney, 1991; Prahalad \& Hamel, 1990).

Ma (1999, p.709) implied that "strategy is about the choice of matching resource commitment with changing opportunities for gaining and sustaining competitive advantages". Besides "competitive advantage grows fundamentally out of value a company is able to create for its buyers that exceeds the company's cost of creating it. Value is what buyers willing to pay, and superior value stems from offering lower prices than competitors for 
equivalent benefits or providing unique benefits that more than offset a higher price" (Porter, 1985, p.3). Thus, it is defined that "competitive advantage is the asymmetry or differential in any company attribute or dimension that allows one company to better serve the customers than others and hence create better customer value" (Ma, 1999, p.709).

In this context, as Porter (Ananymous, 1999, p.21) argued, while a company might be tempted to opt for a location with low labor costs or convenient access to big markets, it also needs to ensure that it will be operating from a competitive base. This would at least involve considering potential locations in the wider context of excellent suppliers, availability of skilled staff and reliable peripheral services. The sourcing from a distance should consider that the supply route was open to all comers, and therefore bestows no competitive advantage. Thus, where the real competitive advantage lied was in localities where conditions were particularly favorable to growth and where there existed a cluster of conditions and organizations that would support and benefit a company's operations. Hence, according to Porter, a cluster is a geographic concentration of interconnected companies and institutions in a particular field, which ultimately benefits all its component parts and the strength of a cluster lies in the fact that its very existence drives competition (Ananymous, 1999, pp.21-22).

On the other side, as Wheelen and Hunger (2004, p.117) indicated, competitive strategy raises the following questions: Should a company compete on the basis of low cost (and thus price), or should it differentiate its products or services on some basis other than cost, such as quality or service? Should the company compete head to head with its major competitors for the biggest but most sought-after share of the market? Should it focus on a niche in which it can satisfy a less sought-after but also profitable segment of the market?

In summary, according to Porter (1985), there are three generic strategies a business company could choose from: cost leadership, differentiation, nichemanship or focus to succeed. "These strategies are called generic because they can be pursued by any type or size of business company, even by not-for-profit organizations" (Wheelen \& Hunger, 2004, p.118). As Manuel and Alcuaz (1996, p.23) have stated, a business company has to have a clear strategy and to succeed as a cost leader a company has to be a low cost producer in order to be able to make a profit while selling at the lowest prices in the market. The cost leader also has to maintain certain threshold levels of product quality, functionality, and service. A product differentiator, on the other hand, was supposed to provide better functionality, quality and service while selling at prices which are not excessive. A niche player could be a cost leader or differentiator in a narrow market segment (Manuel \& Alcuaz, 1996, p.23).

Wheelen and Hunger (2004) further defined that a company's competitive advantage in an industry is determined by its competitive scope, that is, the breadth of the company's or business unit's target market. Before using one of the generic competitive strategies, the company or unit must choose the range of product varieties it will produce, the distribution channels it will employ, the types of buyers it will serve, the geographic areas in which it will sell, and the array of related industries in which it will also compete. This would reflect an understanding of the company's unique resources. Thus, a company or business unit can choose a broad target, that is, aim at the middle of the mass market or a narrow target, namely, aim at a market niche. Combining these two types of target markets with the two competitive strategies results in the four variations of generic strategies depicted in.

According to Porter (1980) and Valos and Bednall (2007, p.149), the differentiator strategy achieves competitive advantage through offering something uniquely different from competitors. In contrast, the cost leader strategy aims to have greater efficiency in production and resource usage. The focus strategy can be adopted by differentiators or cost leaders, but differs in that it targets a market niche rather than the broad market (Porter, 
1980; Valos \& Bednall, 2007, p.149).

\subsection{A conceptual framework for product positioning and global brand management}

It is suggested that, one of the most significant objectives of a company is to gain competitive advantage in the market. In order to get competitive advantage, the company has to determine the attractiveness of a potential market segment to which the product could be targeted. Identification of the competition comes next wherein the company utilizes both the market concept of competition and industry concept of competition to do so and then the company formulates its competitive strategies (Kotler, 2003).

Therefore, product positioning and brand management are necessary and often critical to the development of effective marketing strategies in today's competitive marketplace.

2.2.1 Product positioning and its importance

As Segal and Giaccobe (2002, p.38) have implied, the impetus for a market segmentation strategy is basic as "customers exhibit heterogeneous needs and purchase patterns, and thus respond differently to different marketing stimuli". The benefits of market segmentation and product positioning strategy are closely linked to the market concept. Therefore, the process of segments identification requires the analysis of entire markets, not only focusing on the customers' needs and shopping habits but also conditions and competitive actions.

As today there is a high competition in the business environment and the within the new economy, positioning is referred as an attempt to distinguish a company from its competitors in order to be preferable within the certain market segment or prospect (Zineldin, 2002, p.38). It is mentioned that one of the effective ways to build a strong competitive position is through product positioning, product/service quality and differentiation. In addition, it is required to understand and examine the product positioning strategies and elements of service quality relative to the overall company's marketing strategies (Zineldin, 2002, p.38).

It is obvious that the changes in inter-organizational relations and customer requirements have led the companies to reassess their competitive positions. At this point, the strategic product positioning involves both the company's offering and the company's relations with its business customers as two critical dimensions. As it is indicated, effective positioning is an essential factor in long-term organizational success, and the offering and customer relationships are the two important areas in which the companies have an opportunity for strategic choice (Penttinen \& Palmer, 2007, p.552).

As Domzal and Unger (1987, p.23) pointed out, there were various methods by which companies achieve marketing success and illustrated several positioning strategies for establishing a world brand, segmenting global markets on the basis of consumer similarities and product benefits, and the recognition of universal themes (Domzal \& Unger, 1987, p.23). Moreover, it is indicated that there is a relevance of product positioning within the domain of business marketing through the application of an effective positioning strategies and the business positioning is determined by criteria, such as product quality, relationship building factors, other considerations such as company structures, geographical coverage, breadth of offerings and location in the distribution chain (Kalafatis, Tsogas \& Blankson, 2000, p.416).

In this respect, product positioning can be defined as "the process of shaping the way that customers perceive the company's product" (Husted \& Varble, 1999, p.217). Brands may be positioned as well as products, positioning actually occurs in the customer's mind. Whether or not a marketing manager attempts to position a brand, the customer probably has some perceptions of its attributes and how it compares to other brands (Husted \& Varble, 1999). Ries and Trout (1981) and Ibrahim and Gill (2005, p.173) argued that "the concept of positioning is not only applicable to a brand but also to a company, service, person or place". Hence, this statement is consistent 
with the broad concept of the product, which is defined as physical goods, service, place, person or idea (Kotler, 2000).

Even the company is in consumer market or industrial market, after it chooses a certain segment or segments, it should define which position it wants to be in. Positioning is not only actually a product, but also presentations focusing on circle of business product. It was indicated that all products and brands have some qualities both objective and subjective, consumers consider one or more qualities in their preferences, and they evaluate opponent properties according to these qualities (Evans \& Berman, 1990, p.238). Besides, it is claimed that a key element of the competitive context is the relative positioning of each brand along the company's marketing strategies and the brands vary in the extent to which they are positioned relative to their competitors, in the minds of consumers (Du, Bhattacharya \& Sen, 2007, p.225).

In this context, consumer perceptions are very important. However, while making choice among opponent presentations, consumer will prefer the most advantageous one according to importance of qualities. In addition, "positioning can be done according to specific features of property or advantage or usage situation, opposing to a huge opponent positioning directly or different form that can be done" (Blythe, 2003, pp.84-85). Consequently, to define positioning strategy, firstly, it is necessary to determine qualities and images of every opponent correctly; Then, business defines a place for the product that it presents itself; At this point, that is, while it is defining its own presentations position, it should create customer advantage combination that will be requested by target market not opponents present. Therefore, it is possible to be effected of them by focusing on the reasons of why customer buys its own products not opponent products. In other words, it must be defined clearly firstly in form of strategy planning consciously and systematically by management about "what kind of differences", "which superiorities", "why it must be preferred" have goods and service which will be presented to target market (Blythe, 2003, pp.84-85).

In this respect, the strategic importance of the product positioning decision in achieving success and competitive advantage within the market is a considerable subject. In the literature, there are two phases in the positioning process that were discussed (Punj \& Moon, 2002, p.275). The objective during the first phase is association with the leading brand(s) in the category, while the goal during the second phase is differentiation from the auxiliary brands in the product category. The two phases of the positioning process are interdependent and the each phase's importance depends upon where the brand is to be "positioned" along the brand consideration continuum (Punj \& Moon, 2002, p.275).

It is implied that during the association phase, the objective of the brand is to enter the consideration set and the association judgments are frequently based on similarity judgments at the brand level using attributes that are representative of the product category (Sujan \& Dekleva, 1987). Hence, association can be accomplished by associating the brand with a specific brand or with an idealized composite of real brands that is already in the consideration set, using common attributes among the brands being associated. For new brands with limited resources, a brand's positioning strategy often ends with this step (Punj \& Moon, 2002, p.275).

For instance, the familiar "me too" strategy was given as an example of such an approach (Rossiter, 1997; Punj \& Moon, 2002, p.275). The differentiation phase becomes important for brands with the resources and desire to find a more distinctive identity. Therefore, during this stage, the objective of the brand is to establish a unique image in relation to other brands in the consideration set (Dickson \& Ginter, 1987; Punj \& Moon, 2002, p.275).

At this point, it is seen that the extent to which a brand is successful in attaining the desired positioning depends on how effective it is in achieving the right mix between association and differentiation. It is implied that 
if too much emphasis is initially placed on looking for an association with a category, later it becomes difficult for the brand to differentiate itself. As further, if there is too little emphasis on achieving association with a category, later attempts at differentiation could be meaningless because consumers may be unable to comprehend the unique features of the brand (Punj \& Moon, 2002, p.275). Hence, it is suggested that to achieve the proper amount of association is an important aspect of any product positioning strategy.

\subsubsection{Global branding and its impact on company competitiveness}

It can be suggested that the processes of product positioning and global brand management help for acquiring competitive advantage for a company in global markets. Product positioning and global brand management provides a formulation of competitive marketing strategies and marketing mix for marketing the products and services.

The importance of global branding has increased in industrial contexts and the companies are seeking unique ways to identify their products among their competitors by focusing primarily on the customer (Rosenbroeijer, 2001, p.7). Berthon, Hulbert and Pitt (1999) and Rosenbroeijer (2001, p.7) state that "the function of branding is to create a distinction among entities that satisfy a customer's need, and the primary distinction is the origin of a series of benefits for both the buyer and the seller". As Rosenbroeijer (2001, pp.7-8) implied, branding a product is a common way of creating heterogeneity and the brand is seen as a company's central resource. Thus, all of the investments that are undertaken within the resource mix of a company to support the brand are central to brand management.

Moreover, it is indicated that in consumer marketing, global branding provides points of differentiation between competitive offerings and allows for market positioning in international markets. The brand creates an image of the product in the consumers' mind that is associated with quality, and informs the market of the product's uniqueness in general, or in relation to other competing products (Vranesvic \& Stancec, 2003). Wood and Pierson (2006, p.904) have suggested that the success of brand development may depend on the approach taken to brand description to indicate the use of the marketing mix to position a brand in the market.

At this point, two approaches about brand development were identified (Styles \& Ambler, 1995; Wood \& Pierson, 2006, p.904). The first is the product-plus approach which views branding as an addition to the product and the brand is viewed as an identifier. In this respect, branding would be one of the final processes in new product and service development. The second approach is the perspective in which the focus is the brand itself. Using the marketing mix, the brand is tailored to the needs and wants of a specified target group (Wood \& Pierson, 2006, p.904). The elements of the marketing mix are unified by the brand, and the individual elements of the mix (for example price), are managed in a way which supports the brand message (Styles \& Ambler, 1995; Wood \& Pierson, 2006, p.904).

In this context, as it is mentioned before, there is a crucial importance of the strategic relevance of positioning in today's marketing management. Thus, the brand positioning concept should be examined from a strategic point (Hartmann, Ibanez \& Sainz, 2005, p.10). Brand positioning is described as the part of the brand identity and value proposition that is to be actively communicated to the target audience (Aaker \& Joachimsthaler, 2000, p.46). Hence, it is indicated that brand positioning is based on the interaction of all marketing tools, with an accentuated role for marketing communications because of its relevance in the process of shaping distinct consumer perceptions (Hartmann, et al., 2005, p.10). With this sense, it is suggested that brand positioning is considered as a key tool for brand implementation in today's highly competitive markets (Kotler, 2000).

It is seen that the literature on global branding examines the concepts of brand identity, brand image, brand 
awareness, etc. under the concept of brand management.

It is indicated that evaluating the consequences of brand equity management is one of the most important measurement issues for intangible assets in the new economy (Baldauf, Cravens \& Binder, 2003, p.220). In the literature, there are studies that have addressed the effect of brand equity on the value of the company and addressed the capital market effects of intangible associations such as brand value (Baldauf, et al., 2003, p.220). Moreover, brand equity was also measured and examined in terms of financial performance. For instance, Baldauf, et al (2003, p.220) have investigated the effect of perceived brand equity on brand profitability, brand sales volume, and perceived customer value, and the results of their study have indicated that there is strong effect of perceived quality, brand loyalty and brand awareness on the overall company performance, customer value and willingness to buy.

In this respect, it is suggested that building strong brands has become a marketing priority for many organizations today, because it yields a number of advantages (Yasin, Noor \& Mohamad, 2007, p.38). Strong brands help the company to establish an identity in the market, help for competitive actions, provide larger sales margins, greater intermediary co-operation and support and brand extension opportunities (Delgado-Ballester \& Munuera-Aleman, 2005, p.187). In order to measure the overall value of a brand, the concept of "brand equity" was begun to be examined by several researchers and the value that the brand name brings to the producers, retailers and consumers of the brand was emphasized (Aaker, 1991; Baldinger, 1990; Keller, 1993; Yasin, et al., 2007, p.38).

It is indicated that brand equity refers to "the value inherent in a well known brand name" (Yasin, et al., 2007, p.39). It appears when consumers willingly pay more for the same level of quality due to the attractiveness of the name attached to the product (Bello \& Holbrook, 1995, p.125). Besides, in the marketing literature, brand equity is referred to the intangible brand properties and it is indicated that brand equity arose from customer brand-name awareness, brand loyalty, perceived brand quality and favorable brand symbolisms and associations that provide a platform for a competitive advantage and future earning streams (Aaker, 1991; Yasin, et al., 2007, p.39). Hence, the brand equity can give the company a consumer loyalty and that could bring important achievements in returns for the company.

As it is mentioned, the equity of a brand is the result of consumers' perception of it which is influenced by many factors. However, brand equity should be understood with examining its sources which are the contributing factors to the formation of brand equity in the consumers' mind. These contributing factors involve the marketing mix variables such as advertising, distribution, price and product quality as the contributing factors and the non-marketing mix factors, for example in the buying process, the consumers are not only concern about the quality and price of a product, but also focus on other factors such as the brand's country-of-origin (Yasin, et al., 2007).

In this respect, it is suggested that brand equity represents a product's position in the minds of consumers in the market. It is the well-established representation and meaningfulness of the brand in the minds of consumers that provides equity for the brand name. Kim (1990, p.63) proposed that "a brand is the totality of thoughts, feelings, sensations, and associations it evokes". Therefore, a brand is said to have equity if it has the ability to influence the behavior of those who behold the brand, routinizing their preference, attitude and purchase behavior.

Thus, brand equity is defined as the "consumers' favoritism towards the focal brand in terms of their preference, purchase intention and choice among brands in a product category, that offers the same level of product benefits as perceived by the consumers" (Yasin, et al., 2007, p.39). Keller (1993) has stated that the 
consumers' preference, intention to purchase, and brand choice to a brand indicate the consumers' favorable responses to the marketing mix elements of the brand in comparison with other brands.

\section{The role of positioning and brand management in pursuing competitive advantage}

In order to compete in the market, the companies' managers should evaluate the major characteristics of the market and their products. The markets bring the companies both essential opportunities and difficulties. In other words, the companies have to develop effective competitive strategies in order to survive in the market.

As it is suggested (Kotler, 2003), one of the most significant objectives of a company is to gain competitive advantage in the market. Therefore, the company has to determine the attractiveness of a potential market segment to which the product could be targeted (Kotler, 2003). Identification of the competition comes next wherein the company utilizes both the market concept of competition and industry concept of competition to do so, and then the company formulates its competitive strategies.

As mentioned in this study, market segmentation is the process of dividing the market into similar groups according to the characteristics intended for the product at hand, targeting is the process of selecting the most lucrative market segments for marketing the product and positioning involves the formulation of a definitive marketing strategy around which the product at hand would be finally marketed amongst the target audience. In this context, we can conclude that segmentation, targeting, and positioning are marketing tools used by a company to gain competitive advantage in the market. They help the company to differentiate its product offering from that of its competitors and ensure that the same reaches the exact market profile for which it is intended (Kotler, 2003).

In this context, the process of market segmentation, positioning and branding provides the company to achieve competitive advantage within the market. Targeting, market segmentation and positioning involve the formulation of competitive marketing strategies and marketing mix in order to market the product. Hence, it can be suggested that the companies require to focus on the customers by building a loyal, long-term relationships. In order to be efficient within the competitive environment, the companies need to understand and reassess competition and recognize that there are many different strategies such as market segmentation, product positioning and branding for addressing the competition.

\section{Conclusion}

It is indicated that because of globalization and advanced technologies, the customers behaviors as well as the competition strategies of companies have changed and will go on to change (Dereli \& Durmusoglu, 2006). It is mentioned that the competition by classical strategies such as low cost and high quality can not be achieved, although the customers ask for high-quality and low-cost products and services, and their needs are now rapidly changing, highly specific and customized. Moreover, the product life cycles are shortened and the importance of new product development was realized. Since it became a necessity for the companies to respond to the changes in environment, the companies have to provide a suitable product variety in order to survive and be competitive in the market.

In this respect, the companies - especially international and multinational companies-should look for powerful competition strategies. It is suggested that the companies should begin to point out that the technology and investing in technology is the most valuable competition asset of the company that creates value for the products, services and the company itself. It should also be considered that as the companies realize that their 
products become homogeneous in the customers' eyes, the companies differentiate their technology and this is attained through the companies' effective branding strategy.

It is indicated that the companies which have not realized the role of brands in global competition for the past two decades has lost some of their market power. Especially, the companies that are in retail, service, manufacturing and producing technology products require brand management strategy as a key way of differentiating themselves from their global competitors (Dereli \& Durmusoglu, 2006, p.1757). In this respect, it is suggested that the companies should focus on to produce innovative and technology products as well as they invest on branding and implement an effective brand management strategy along with their technology investment. At this point, it is suggested that the companies should use global branding strategy as a way of marketing strategy for the achievement of competitive advantage within the marketplace.

In this context, it can be stated that the process of positioning and global branding set the pace for acquiring competitive advantage for a company. Positioning and global branding involve formulation of competitive marketing strategies and marketing mix in order to market the product. This study tried to explore these two strategies and discusses the factors and implications involved therein. Consequently, it can be implied that, the companies need to focus on those customers whose needs they can profitably meet and with whom they can build a loyal, long-term relationship despite the competition. Companies need to understand and track competition constantly and recognize there are many different strategies in which to address the competition, and also need to describe those segments they can most profitably serve in terms of multiple variables.

\section{References:}

Aaker, D. A. \& Joachimsthaler, E.. (2000). Brand leadership. New York: The Free Press.

Aiginger, K.. (2006). Revisiting an evasive concept: Introduction to the special issue on competitiveness. J Ind Compet Trade, 6, 63-66.

Baldauf, A., Cravens, K. S. \& Binder, G.. (2003). Performance consequences of brand equity management: Evidence from organizations in the value chain. Journal of Product \& Brand Management, 12(4), 220-236.

Barney, J. B.. (1991). Firm resources and sustained competitive advantage. Journal of Management, 17, 99-120.

Bello, D. C. \& Holbrook, M. B.. (1995). Does an absence of brand equity generalize across product classes? Journal of Business Research, 34(2), 125-131.

Blythe, J.. (2003). Principles of manrketing. Odabaş1, Y. Trans. İstanbul: Bilim Teknik Publishing.

Delgado-Ballester, E. \& Munuera-Aleman, J.. (2005). Does brand trust matter to brand equity? Journal of Product \& Brand Management, 14(3), 187-196.

Dereli, T. \& Durmusoglu, A.. (2006). Branding and technology management. Technology Management for the Global Future, 4(8), 1757-1763.

Domzal, T \& Unger, L.. (1987). Emerging positioning strategies in global marketing. Journal of Consumer Marketing, 4(4), 23-37.

Du, S., Bhattacharya, C. B. \& Sen, S.. (2007). Reaping relational rewards from corporate social responsibility: The role of competitive positioning. International Journal of Research in Marketing, 24, 224-241.

Evans, J. R. \& Berman, B.. (1990). Marketing (4th ed.). New York: Macmillan Publishing.

Hartmann, P., Ibanez, V. A. \& Sainz, F. J.. (2005). Green branding effects on attitude: Functional versus emotional positioning strategies. Marketing Intelligence \& Planning, 23(2), 9-29.

Husted, S. W. \& Varble, D. L.. (1999). Principles of modern marketing. Boston: Alyyn \& Bacon Publishing.

Ibrahim, E. E. \& Gill, J.. (2005). A positioning strategy for a tourist destination, based on analysis of customers' perceptions and satisfactions. Marketing Intelligence \& Planning, 23(2), 172-188.

Kalafatis, S. P., Tsogas, M. H. \& Blankson, C.. (2000). Positioning strategies in business markets. Journal of Business \& Industrial Marketing, 15(6), 416-437.

Keller, K. L.. (1993). Conceptualizing, measuring and managing customer-based brand equity. Journal of Marketing, 57, 1-22.

Ketels, C. H. M.. (2006). Michael Porter's competitiveness framework-recent learnings and new research priorities. Journal of 
Industry, Competition and Trade, 6, 115-136.

Kim, P.. (1990). A perspective on brands. The Journal of Consumer Marketing, 7(4), 63-67.

Kotler, P.. (2000). Marketing management (11th ed.). New Jersey: Pearson Education, Inc.

Kotler, P.. (2003). Marketing (3rd ed.). İstanbul: Sistem Publishing.

Ma, H.. (1999). Anatomy of competitive advantage: A select framework. Management Decision, 37(9), 709-718.

Manuel, A. \& Alcuaz, J.. (1996). Competitive advantage: Focus for market leadership. Business World, April, 23-26.

Penttinen, E. \& Palmer, J.. (2007). Improving firm positioning through enhanced offerings and buyer-seller relationships. Industrial Marketing Management, 36, 552-564.

Porter, M. E.. (1980). Competitive strategy. New York: Free Press.

Porter, M. E.. (1985). Competitive advantage. New York: Free Press.

Porter, M. E.. (1990). The competitive advantage of nations. New York: Free Press.

Porter, M. E.. (1999). Creating advantage. Executive Excellence, 16(11), 13-16.

Porter on the competitive advantage of clusters. (1999). Strategic Direction, 150, 21-22.

Prahalad, C.K. \& Hamel, G.. (1990). The core competence of corporations. Harvard Business Review, May-June, 79-91.

Punj,G. \& Moon, J.. (2002). Positioning options for achieving brand association a psychological categorization framework. Journal of Business Research, 55, 275-283.

Rodríguez-Pinto, J., Rodríguez-Escudero, A. I. \& Gutiérrez-Cillán, J.. (2008). Order, positioning, scope and outcomes of market entry. Industrial Marketing Management, 37, 154-166.

Rosenbroeijer, C. J.. (2001). Industrial brand management: A distributor's perspective in the UK fine-paper industry. Journal of Product \& Brand Management, 10(1), 7-24.

Segal, M. N. \& Giacobbe, R. W.. (2004). Market segmentation and competitive analysis for supermarket retailing. International Journal of Retail \& Distribution Management, 22(1), 38-48.

Sujan, M. \& Dekleva, C.. (1987). Product categorization and inference making: some implications for comparative advertising. Journal of Consumer Research, 14, 372-378.

Valos, M. J. \& Bednall, D. H. B.. (2007). The impact of Porter's strategy types on the role of market research and customer relationship management. Marketing Intelligence \& Planning, 25(2), 147-156.

Vranesvic, T. \& Stancec, R.. (2003). The effect of the brand on the perceived quality of food products. British Food Journal, 105(11), 811-825.

Wheelen, T. L. \& Hunger, J. D.. (2004). Strategic management and business policy (9th ed.). New Jersey: Prentice Hall.

Wood, L. M. \& Pierson, B. J.. (2006). The brand description of Sainsbury's and Aldi: Price and quality positioning. International Journal of Retail \& Distribution Management, 34(12), 904-917.

Yasin, N. M., Noor, M. N. \& Mohamad, O.. (2007). Does image of country-of-origin matter to brand equity? Journal of Product \& Brand Management, 16(1), 38-48.

Zineldin, M.. (2002). Managing in the @ age: Banking service quality and strategic positioning. Measuring Business Excellence, 6(4), $38-43$.

(Edited by Ruby and Chris) 